\title{
EFFECTIVENESS OF ADIWIYATA IN THE CHARACTER OF CARING FOR THE ENVIRONMENT OF STUDENTS Syahrial Syahrial $^{1}$, Asrial Asrial ${ }^{2}$, Husni Sabil ${ }^{3}$, Arsil Arsil ${ }^{4}$ \\ ${ }^{1,2,3,4}$ Faculty of Teaching and Education, Universitas Jambi, Jambi, Indonesia. Email: ${ }^{1}$ syahrial.karea@gmail.com, ${ }^{2 *}$ porigih@gmail.com, ${ }^{3}$ husnisabil@unja.ac.id, ${ }^{4}$ arsil@unja.ac.id
} Article History: Received on $30^{\text {th }}$ January 2020, Revised on $19^{\text {th }}$ April 2020, Published on $19^{\text {th }}$ May 2020

\begin{abstract}
Purpose of the study: This research aims to look at the effectiveness of the adiwiyata program in the character of caring for the environment of students.
\end{abstract}

Methodology: Using mixed methods with the type of sequential explanatory using 220 respondents using questionnaire instruments, interviews, and documentation.

Main Findings: From the results of the questionnaire given shows that elementary school teacher education students at Jambi University have a good category in caring about the environment, this is reinforced by the results of documentation and interviews that have been conducted, that students already care about the environment, and know that throwing trash in its place and protecting the campus environment is the right activity.

Applications of this study: implementing the adiwiyata program on campus can foster the character of caring for the environment owned by students so that students are able to protect the environment around themselves of their own volition without being instructed.

Novelty/Originality of this study: The renewal of this research is the implementation of the adiwiyata program to see the effectiveness of growing the character of caring for the environment.

Keywords: Adiwiyata, Character, Education, Environment, Pre-Service Teacher.

\section{INTRODUCTION}

Education is a process carried out by each individual in developing their abilities. Education is very important for all people. Education has an important role in the creation of progress in a nation (Astalini et al., 2019; Asrial et al., 2019). Without education, many people do not know the importance of education. According to Law No. 20 of 2003, about the national education system, education is an effort to create a learning atmosphere so as to develop their potential as well as the skills needed by countries, nations, communities, and individuals. From these explanations, that education itself has a learning process that can bring humans into a better person than before.

The progress of a nation is determined by the quality of education because education as a means to educate the nation has an important role in it. Education can develop quality human resources (HR), with indicators of qualified experts, skilled, creative, innovative, and have a positive attitude (attitude and behavior) (Kurniawan et al., 2019; $\underline{\text { Syahrial et al., }}$ 2019; Darmaji et al., 2019). Attitude is a concept that is quite important, often discussed, and becomes an important study in social science. By studying attitudes, it can help us in understanding the process of awareness that determines real actions and actions that might be carried out by individuals in their social life (Asrial et al., 2019; Maison et al., 2019). Environmental care is an expression of the mental attitude of individuals that is reflected in their behavior. Environmental concern is an act and attitude that seeks to prevent the destruction of the environment, as well as development efforts in repairing natural damage, one of them with an adiwiyata program.

The adiwiyata program must also be implemented on the campus of the Elementary School Teacher Education Study Program (PGSD), FKIP Muara Bulian. As a campus that becomes a place to study for prospective elementary school teachers must stand at the forefront in environmental management. Students who will become teachers must be the main actors in this problem so that after finishing studying on campus and serving the country in the field of education, they already have the soul and character of environmental care who are qualified to educate their students on the same problem. During the study period on campus (a minimum of eight semesters) is sufficient time to learn the concepts and practices of adiwiyata that will be very useful for them in shaping the environmental care character of students in the future (Hidayatullah, 2016; Parker, Prabawa-Sear, \& Kustiningsih, 2018). Thus the PGSD campus that is insightful, attitude-based and adiwiyata must be realized at the Jambi Muara Bulian University Campus.

At this time, the PGSD Campus is still very far from the character of caring for the environment. Based on the observations and experiences of researchers who have served on the PGSD campus since 2002, the character of caring for the environment of campus people is still far from expected (Anisah, 2017). Based on the facts found, the researchers felt the need to make changes in the field of environmental care character education for the people of the Muara Bulian PGSD Campus by conducting a Campus Action Research (PTK) by instilling and implementing the adiwiyata concept in the Muara Bulian PGSD Campus.

The campus, including the PGIP campus FKIP Jambi University in Muara Bulian, is a formal educational institution, one of the ways in which prospective teachers gain knowledge, forge attitudes and teacher mentality, and practice 
learning skills. In short, the PGSD campus is a formal educational institution that is an educational unit that is designed in such a way as to be able to form prospective teachers with the high intellectual personality to educate the nation's life (Matthews, 1985). Based on this description, the PGSD campus must become a formal educational institution that functions as a place of learning so that teachers can experience changes, both intellectually and emotionally, which in the future will play an important role in educating students at the elementary school level, in accordance with National Education System Law No. 20 of 2003. While elementary school is a basic education level where students get an initial education that will shape and instill good moral values (such as character care for the environment) in accordance with applicable norms, not just mere knowledge. Thus prospective teachers must be able to prepare themselves as fully as possible in all aspects, including character building so that they can be an example and role model for their students (Chatzifotiou, 2006; Parker, 2018). The Adiwiyata Campus Program is one of the very positive programs that will be able to shape the attitudes and characteristics of environmental care prospective teachers that they will transmit to their students later in their capacity as elementary school teachers (OSDBA, 2000).

Therefore this study aims to see the implementation of the adiwiyata program in the character of environmental care for students on the PGSD campus of Jambi University, with the following research questions.

How is the implementation of the adiwiyata program in fostering the character of environmental care in PGSD University of Jambi?

What is the effectiveness of the adiwiyata program for the character of caring for the student's environment?

\section{METHODOLOGY}

\section{Research Design}

This research uses a mixed-method approach. Martens (2010) "mixed methods method is a method that combines quantitative and qualitative methods in answering a research question with each answering with a different methodological approach. The mixed-method approach is used with the type of sequential explanatory design. The sequential explanation strategies for the mixed-method design that often apply to researchers with strong quantitative tendencies, meaning that quantitative data are strengthened by the qualitative data that will be obtained (Creswell, 2012).

\section{Research subject}

Where the quantitative activities were given a questionnaire to see the effectiveness of the adiwiyata program, which was seen based on the character of environmental care for students on campus, they were then followed by qualitative activities that documented the activities of students on campus through photographs and interviews with students. This study uses 220 PGD students from Jambi University, who is on the campus of PGD University Jambi using total sampling techniques. The total sampling technique is a sample collection technique using the total of the total population (Kerlinger, 2014; Cohen, Manion \& Morrison, 2007) then interviewing only 20 students who are willing to do the interview. The instruments in the study used questionnaires, documentation, and interviews.

\section{Research Instrument}

In the first data collection process, because it uses the type of sequential explanatory, the data obtained first is quantitative data through an environmental care questionnaire. The environmental care questionnaire was adapted by (Riskina \& Listyaningsih, 2019), with 32 valid statements, then has a Cronbach alpha value of 0.72 that uses a Likert 4 (four) and then conducts semi-structured interviews to confirm the quantitative results that have been conducted. Then to process the data, SPSS 21 is used to look for descriptive statistics to see quantitative data, while for qualitative data using miles \& Huberman, namely data reduction, data display, and conclusions. Descriptive statistics are presented in summary frequencies, such as mean, mode, median, minimum, maximum, and standard deviation (Cohen, Manion \& Morrison, 2007). In this study, the descriptive statistics used are mean, min, max, and category.

Below is a category of the character of caring for the environment of students, like table 1 below:

Table 1: Categories of characters caring for the environment of students

\begin{tabular}{ll}
\hline Category & Interval \\
\hline Very Not Good & $32.0-56.0$ \\
\hline Not Good & $56.1-80.0$ \\
\hline Good & $80.1-104.0$ \\
\hline Very Good & $104.1-128.0$ \\
\hline
\end{tabular}

\section{Analysis of Data}

All data obtained from questionnaires were collected and then calculated and assisted with the SPSS 21 application to obtain descriptive data. Descriptive statistics are provided to calculate the frequency, percentage, average, min, and a 
max of the sample (Creswell, 2012; Cohen, Manion \& Morrison, 2007). And followed by interviews that are used to strengthen the results of quantitative data.

\section{RESULTS/FINDINGS}

The results of the questionnaire for the students' environmental care characteristics in seeing the effectiveness of the adiwiyata program were processed and the results were processed using the SPSS 21 application which can be seen in the table below:

Table 2: Results of the student's environmental care characters in the adiwiyata program

\begin{tabular}{|c|c|c|c|c|c|c|}
\hline \multicolumn{3}{|l|}{ Classification } & \multirow{2}{*}{ Mean } & \multirow{2}{*}{ Min } & \multirow{2}{*}{$\operatorname{Max}$} & \multirow{2}{*}{$\%$} \\
\hline Range & Respond & Total & & & & \\
\hline $32.0-56.0$ & Not very good & 13 & \multirow{4}{*}{97.5} & \multirow{4}{*}{49} & \multirow{4}{*}{121} & 5.9 \\
\hline $56.1-80.0$ & Not good & 31 & & & & 14.1 \\
\hline $80.1-104.0$ & Good & 138 & & & & 62.7 \\
\hline $104.1-128.0$ & Very good & 38 & & & & 17.3 \\
\hline TOTAL & & 220 & & & & 100 \\
\hline
\end{tabular}

From table 2, which came from 220 respondents from the Jambi university basic education students after they were obtained and the results obtained using the SPSS 21 application program rock, students' environmental care characters had a good category of $62.7 \%$ for 138 students out of 220 total students, very good $17.3 \%$ for a total of 38 students out of 220 total students. Not good at $14.1 \%$ for 31 students out of 220 total students, and very bad $5.9 \%$ for 13 students out of 220 total students. Of the 220 students, they had an average grade of 97.5 , a maximum score of 121 , and a minimum grade of 49 .

Then, apart from the questionnaire that has been distributed, the researcher also looks at the effectiveness of the adiwiyata program to the students' environmental care characteristics through documentation, as shown below.

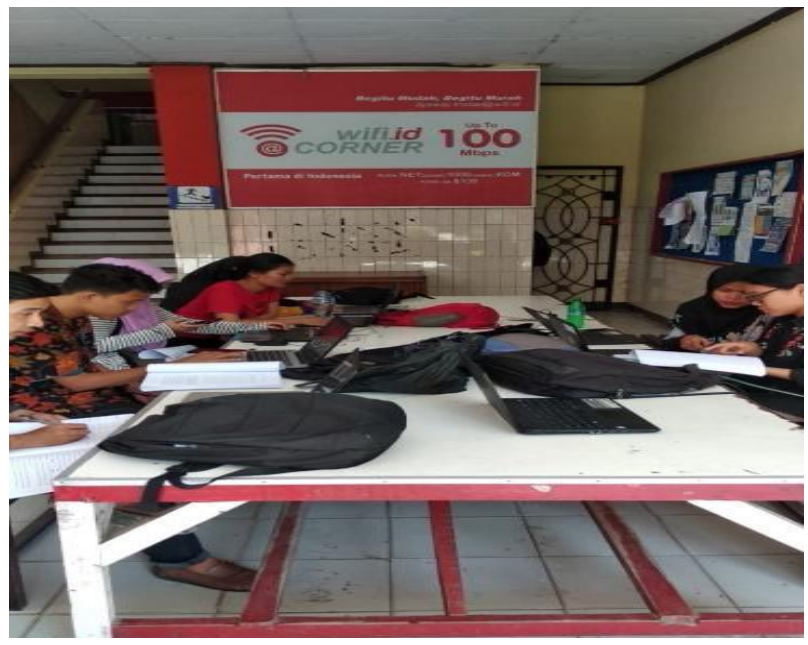

Figure 1: Student Activities

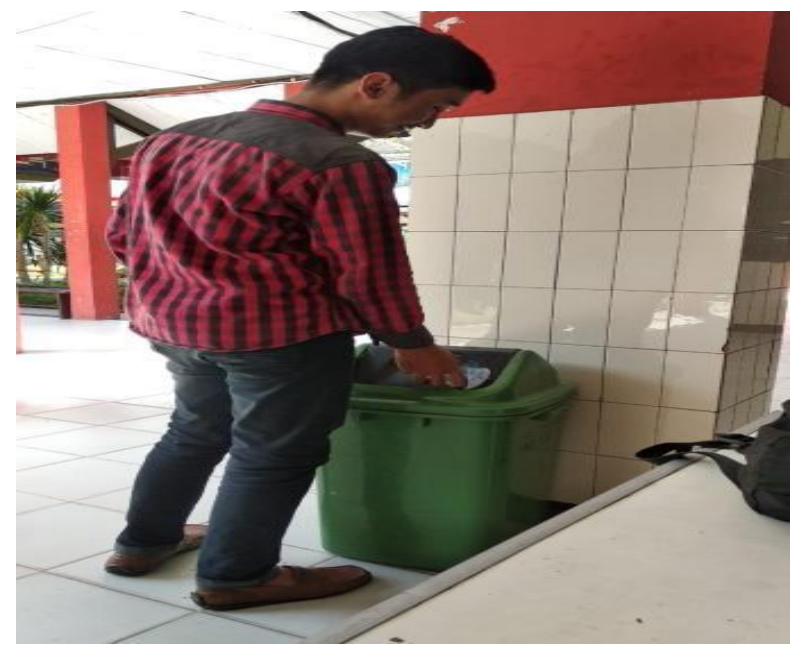

Figure 2: A student immediately throws his trash into the trash, not leaving it carelessly 
From Figures 1 and 2, it can be seen that usually when students do gathering activities, they will definitely leave rubbish, either food or drink waste, but when the adiwiyata program is implemented, students begin to understand by caring about their surroundings, such as throwing trash in its place and paying more attention to the environment surrounding. Therefore, it can be seen that the adiwiyata program is very effective for elementary school teacher education students in protecting the surrounding environment, in this case, the elementary school teacher education campus, Jambi University.

\section{DISCUSSION/ANALYSIS}

The results of the questionnaire analysis in table 2, for the character of environmental care students of elementary school teacher education at the University of Jambi, have a good ability of 62.7\% (138 of 220) students. The character can be seen from students starting to care about the surrounding environment, with proof that there is no more garbage left where students usually sit. This is also reinforced from the results of the interviews that have been carried out as follows.
"When you are gathering with your friends and eating something and there is trash, what do you do?"
"I am with my friends from now on, always protecting the environment, both when we gather when there is trash, definitely immediately throw it into the trash."
"What is your role in protecting the environment? Specifically, removed from the elementary school teacher education at Jambi University?"

"We are in the campus, always doing cleaning activities or often referred to as mutual cooperation on every Friday, this is always done once a week, whose members are all students, educators, and lecturers who are in the elementary school teacher education at Jambi University."

From the results of the interview, we can see that the implementation of the adiwiyata program in growing the character of caring for the environment is very effective, this is evidenced by the results of the questionnaire, documentation, and interviews that have been conducted.

According to Prabawa-Sear (2018) that the indicator of caring for the environment is to always maintain the preservation of the surrounding environment, not taking, cutting or pulling plants that are along the road, not scribbling, carving the writing on trees, stones, roads or walls, always throw garbage in its place, do not burn rubbish around the housing, carry out activities to clean the environment, hoard used goods and clean up trash that clogs waterways.

Moral awareness in students can be obtained from observing the actions and behavior of teachers in daily life on campus, so students also realize that having the same awareness as lecturers, for example, lecturers always remind students of the clean Friday program in order to always maintain the cleanliness of the campus environment. Knowledge of moral values can be done by respecting and protecting the surrounding environment; for example, by taking part in a program to maintain environmental hygiene, students participate in maintaining environmental cleanliness. Determination of perspective is the ability to see from the perspective of others, for example by looking at it from another point of view if it does not save energy it will lead to waste of energy, so it must determine which perspective will be done (Dean \& Major, 2008; Prabawa-Sear, 2018). Moral thinking, that is, understanding what is meant by moral, means that students must understand why they must program a clean love of the environment for their friends. Decision making is related to the way a person acts; in this case, it means related to how students make decisions in caring for and loving the environment, whether or not to protect the environment. This personal knowledge means the ability to review one's own behavior (Chawla \& Derr, 2012; Nilan et al., 2011). In this case, it means that students must be able to evaluate whether they have taken care of the surrounding environment by way of example if there is rubbish scattered about in the classroom whether students are willing to clean or not.

Through the adiwiyata school program, students know the importance of maintaining environmental cleanliness. In terms of teaching the importance of maintaining cleanliness in the school environment, one example is that lecturers participate in Friday clean activities by doing community service at school. So, students will have moral knowledge from what the lecturer teaches.

Moral feelings have several parts in it. Namely, there is conscience, self-esteem, empathy, good loving things, selfcontrol, humility. Conscience is related to many who know what is right but are reluctant to do so, for example, by knowing that maintaining environmental cleanliness and saving energy such as turning off lights after class time is over (Stevenson, 2007; Parker, 2017). Self-esteem relates to someone being able to participate in his own assessment, for example, students in a class do community service, while one student does not want to do community service, so students who have self-esteem will not affect their peers so that they maintain the cleanliness of the classroom environment. Empathy is related to the ability to get out of oneself and be able to feel other circumstances outside of him, for example, the ability to feel the state of the environment when the environment becomes very uncomfortable and has a lot of damage, resulting in the sense of empathy for the surrounding environment. To love good things, one of them is by loving the environment (Ma'ruf, Surya, \& Apriliany, 2016). Self-control is used to refrain from damaging, 
cutting down, or uprooting plants or plants in the surrounding environment. Humility is related to openness to the truth and the desire to act; it is related to openness to act in maintaining the beauty and preservation of the surrounding environment.

Whereas in this study included in the moral feeling that is about the attitude of caring for the environment through the adiwiyata school program with the second indicator that is programing clean love for the environment. In the school program, adiwiyata lecturers will instill in students to have empathy, love, and care for the environment. Then, over time, students will have moral feelings. One example is the lecturer instilling in his students not to cut down or uproot plants carelessly on campus; this will make students care about the environment.

Moral Action there are three parts in moral action, namely competence, desire, and habit. Moral competence has the ability to transform moral judgments and feelings into effective actions; this means the ability to change the knowledge held about the importance of caring for the surrounding environment into a definite action (Dillon, Kelsey, \& DuqueAristazbel, 1999; Nilan, \& Wibawanto, 2015). Desire is needed as a controller of thought, in this case, the desire is needed when students want to take action to preserve the environment, for example, the desire is needed first when students want to clean classrooms that have trash scattered about. Often someone does good things because of habitual encouragement, for example in this case students are accustomed to cleaning classrooms because they have been accustomed to class pickets, so students are accustomed to cleaning classrooms.

Whereas in this study included in the moral action is the attitude of caring for the environment through adiwiyata school programs with the habit of maintaining the cleanliness of the surrounding environment. Students will be able to have a component of moral action. Through habituation, students can love and care about the surrounding environment. One example is that the lecturer accustoms students to clean bathrooms and maintains the cleanliness of the campus canteen, gazebo so that students have moral actions.

\section{CONCLUSION}

From the results of the questionnaire given shows that elementary school teacher education students at Jambi University have a good category in caring about the environment, this is reinforced by the results of documentation and interviews that have been conducted, that students already care about the environment, and know that throwing trash in its place and protecting the campus environment is the right activity.

\section{LIMITATION AND STUDY FORWARD}

This research only sees the extent of the effectiveness of the Adiwiyata program in improving the character care environment of PGSD Universitas Jambi.

\section{ACKNOWLEDGMENT}

Thanks to all respondents who have prepared to be sampled in the research, researchers do not know what to say availability respondents in helping to complete this research, again I thank you.

\section{AUTHORS CONTRIBUTION}

Syahrial is an associate professor in the study of indigenous knowledge language and linguistic field. Language as a cultural product of local wisdom is one of the markers of civilization. Ethnic language (local) has an important function and role as important as the national language and international language as a bridge in global communication. Decreasing the vitality of ancestral languages will affect the safeguarding of local wisdom values. Noble advice contained in culture will stop being inherited as language skills fade. So from that, the value of local wisdom must be maintained, explored, and developed for students. This is intended so that later the development of culture and science becomes the basis for human resource development. Syahrial is a member of the research group ethno constructivism and works at the Elementary Teaching and Education Program, Universitas Jambi. The role of this research is as the coordinator for making articles, instruments, taking data, and managing data.

Asrial is a professor in the study of indigenous knowledge chemical fields. This knowledge can be applied to $21 \mathrm{st}$ Century learning at the elementary, junior, and senior high school levels. And preparing teacher candidates to understand the value of local wisdom to improve competence pedagogically. By applying education based on local wisdom it is hoped that it will be able to create education that gives meaning in the learning process for students. So that education is able to create young generations who are able to preserve and love their own culture. In addition, education must be able to shape human character with high integrity and great character and dignity in accordance with the spirit of education which is humanizing humans. Asrial is the chair of the research group ethno constructivism and that group is aimed at analyzing all the values of local wisdom to serve as a medium and source of learning. The role of this research is to create instruments and input data.

Husni Sabil is a lecturer in faculty of teaching and education, as well as members of Ethno Constructivism group contributions on this research, are maintainers and analyzing quantitative data. 
Arsil is a lecturer in faculty of teaching and education, as well as members of Ethno Constructivism group contributions to this research, are maintainers and analyzing qualitative data.

\section{REFERENCES}

1. Anisah, S. (2017). Implementasi pendidikan lingkungan hidup dalam program adiwiyata di SD Muhammadiyah Kleco Kota Gede Yogyakarta. (Bachelor), Universitas Islam Negeri Sunan Kalijaga, Yogyakarta.

2. Astalini., Kurniawan, D. A., Sulistiyo, U., Perdana, R., Susbiyanto, S. (2019). E-Assessment Motivation in Physics Subjects for Senior High School. International Journal of Online and Biomedical Engineering (iJOE). 15(9), 4-15. https://doi.org/10.3991/ijoe.v15i11.10843

3. Darmaji., Kurniawan, D. A., Astalini., Lumbantoruan, A., \& Samosir, S. C. (2019). Mobile Learning In Higher Education For The Industrial Evolutioin 4.0: Perception and Response of Physics Practicum. International Journal of Interactive Mobile (IJIM), 13(9), 4-20. https://doi.org/10.3991/ijim.v13i09.10948

4. Asrial., Syahrial., Kurniawan, D. A., Perdana, R., Nugroho, P. (2019). Supporting Technologi 4.0: Ethnoconstructivist Multimedia for Elementary Schools. International Journal of Online and Biomedical Engineering (iJOE). 15(9), 4-15. https://doi.org/10.3991/ijoe.v15i14.11365

5. Asrial., Syahrial., Kurniawan, D. A., Subandiyo, M., Amalina, N. (2019). Exploring obstacles in language learning among prospective primary school teacher. International Journal of Evaluation and Research in Education (IJERE), 8(2), 249-254. https://doi.org/10.11591/ijere.v8i2.16700

6. Chawla, L. and Derr V. (2012). The development of conservation behaviors in childhood and youth. In SD. Clayton (ed.), The Oxford handbook of environmental and conservation psychology. New York: Oxford University Press, pp. 527-555.

7. Chatzifotiou, A. (2006). Environmental education, national curriculum and primary school teachers: findings of a research study in england and possible implications upon education for sustainable development. The Curriculum Journal, 17(4), 367-381. https://doi.org/10.1080/09585170601072478

8. Cohen, L., Manion, L., \& Morrison, K. (2007). Research Methods In Education : Routledge.

9. Council, N. R. (2003). Environmental information for naval warfare. Washington: The Natinal Academies Press.

10. Cochrane, J. (1984). Environmental education in Indonesia and the Yayasan Indonesia Hijau. Indonesia Circle. School of Oriental \& African Studies. Newsletter, 12(33), 23-26. https://doi.org/:10.1080/03062848408729573

11. Creswell. JW (2012). Research Design Qualitative, Quantitative, And Mixed Method Aproach. Singapore : SAGE Publications Asia-Pacific

12. Dean, R.A.K. and Major J.E. (2008). From critical care to comfort care: the sustaining value of humor. Journal of Clinical Nursing. 17(8): 1088-1095. https://doi.org/10.1111/j.1365-2702.2007.02090.x

13. Dillon, J., Kelsey, E. and Duque-Aristazabel, A.M. 1999. Identity and culture: theorising emergent environmentalism. Environmental Education Research. 595-405. https://doi.org/10.1080/1350462990050405

14. Hidayatullah. (2016). Implementasi Program Adiwiyata di SD Islam Al-Azhar 29 BSB Semarang. (Bachelor), Universitas Islam Negeri Wali Songo, Semarang.

15. Kerlinger, F. N. (2014). Foundations of behavioral research. Yogyakarta: Gadjah Mada

16. Kurniawan, D. A., Asrial., Syahrial., Salsabila, W. S., Kurniawati, E. F., Anandari, Q. S., Perdana. R., Lumbantoruan, A., Nasih, N., Samosir, S. C., Dewi, U. P. (2019). Etnoscience Investigation in Pimary Schools: Impact on Science Learning. Universal Journal of Educational Research. 7(12), 2789-2795. https://doi.org/10.13189/ujer.2019.071229

17. Martens D M. (2010) Research And Evaluation In Education And Psychology Integrating Diversity With Quantitative, Qualitative, And Mixed Methods. Singapore: SAGE Publications Asia-Pacific

18. Maison., Astalini., Kurniawan, D. A., Perdana, R., Anggraini, L. (2019). The Phenomenon of Physicology Senior High School Education: Relationship of Students' Attitudes towards Physics, Learning Style, Motivation. Universal Journal of Educational Research. 7(10), 2199-2207. https://doi.org/10.13189/ujer.2019.071018

19. Matthews, M. H. (1985). Environmental capability of the very young: Some implications for environmental education in primary schools. Educational Review, 37(3), 227-239. https://doi.org/10.1080/0013191850370303

20. Ma'ruf, M., Surya, S. and Apriliany, P.D. 2016. Knowledge, attitudes and behavior of university students towards environmental issues in Indonesia. Sains Humanika. 8(1-2): 81-88. https://doi.org/10.11113/sh.v8n1-2.836

21. Nilan, P. \& Wibawanto, G.R. (2015). ‘Becoming' an environmentalist in Indonesia. Geoforum. 62(2): 61-69. https://doi.org/10.1016/j.geoforum.2015.03.023

22. Nilan, P., Parker L., Bennett L., \& Robinson K. (2011). Indonesian youth looking towards the future. Journal of Youth Studies. 14(6): 709-728. https://doi.org/10.1080/13676261.2011.580523 
23. OSDBA, O. o. S. D. B. f. A. (2000). Lessons from school-based environmental education programs in three African countries. Washington: GreenCOM Project.

24. Parker, L. (2017). Religious environmental education? The new school curriculum in Indonesia. Environmental Education Research. 23(9): 1249-1272. https://doi.org/10.1080/13504622.2016.1150425

25. Parker, L. (2018). Environmentalism and education for sustainability in Indonesia. Indonesia and the Malay World, 46(136), 235-240. https://doi.org/:10.1080/13639811.2018.1519994

26. Parker, L., Prabawa-Sear, K., \& Kustiningsih, W. (2018). How young people in Indonesia see themselves as environmentalists. Indonesia and the Malay World, 1-20. https://doi.org/:10.1080/13639811.2018.1496630

27. Prabawa-Sear, K. (2018). Winning Beats Learning: Environmental education in Indonesian senior high schools. Indonesia and the Malay World, 1-20. https://doi.org/:10.1080/13639811.2018.1496631

28. Riskina, M, D., \& Listyaningsih. (2019). Studi Deskriptif Tentang Sikap Peduli Lingkungan Melalui Program Sekolah Adiwiyata di SMAN 2 Pamekasan. Kajian Moral dan Kewarganegaraan 7 (1), 1-15,

29. Rokhmani, T. A. (2016). Implementasi pendidikan karakter peduli lingkungan di SD Negeri Gedongkiwo Yogyakarta. (Bachelor), Universitas Negeri Yogyakarta, Yogyakarta.

30. Syahrial., Asrial., Kurniawan, D. A., Chan, F., Hariandi. A., Pratama, R. A., Nugroho. P., Septiasari. R. (2019). The Impact of Ethnoconstructivism in Social Affairs on Pedagogic Competences. International Journal of Evaluation and Researcn in Education (IJERE). 8(3), 409-416. http://doi.org/10.11591/ijere.v8i3.20242

31. Stevenson, R.B. (2007). Schooling and environmental education: contradictions in purpose and practice. Environmental Education Research. 13(2): 139-153. http://dx.doi.org/10.1080/13504620701295726

32. The Law of the Republic of Indonesia. Number 20 year 2003 about the national education system. 